\title{
Socio Economic Profile of Jaffrabadi Buffalo Farmers in Saurashtra Region
}

\author{
Shilpa Jayebhaye ${ }^{1}$, Menka Jayebhaye ${ }^{1}, \operatorname{Vinod~Potdar}^{2 *}$, Tejashree Shirsath ${ }^{2}$, \\ Velu Dhanikachalam ${ }^{3}$, Santosh Kumar Jadhav ${ }^{3}$, Suresh B. Gokhale ${ }^{4}$ \\ and Marimuthu Swaminathan ${ }^{5}$
}

Central Research Station, BAIF Development Research Foundation, Uruli Kanchan Pune-412202, India

*Corresponding author

\section{A B S T R A C T}

The livestock survey of Jaffrabadi buffalo conducted in five districts of Saurashtra region of Gujrat state. The data collected from 1045 farmers through face to face

\section{Keywords}

Socio economic profile, Farmers land holding, Farmer's occupation

\section{Article Info}

Accepted: 10 April 2020 Available Online: 10 May 2020 interview from Amreli, Rajkot, Junagadh, Bhavnagar and Girsomnath districts as per farmer's population 57, 21, 12, 6 and $4 \%$ respectively. The $50 \%$ of total farmers were practising Agricultural farming as their main occupation, the percentage fraction of farmers involved in other activities as main occupation were 31in Dairying, 12 in working as labour and 7 in service. According to land distribution, $11 \%$ were large (above 2.5 acres) farmers, the fraction of marginal, small landholders and landless was 32, 30 and 26\% respectively. It was observed that $47 \%$ farming families consume boiled milk, $38 \%$ consume raw milk and $16 \%$ consume both raw and boiled milk. The pattern of animal drinking watering provision system was studied. In the study watering of animal's percentage was studied as co- manual and own. It was found that 56 were Co-manual, 41 own and 3 own and co-manual type. More than half the fraction (57\%) farmers preferred Stall feeding while $43 \%$ followed grazing. For breeding animals, both natural (41 per cent) and artificial insemination method (59 per cent) were followed.

\section{Introduction}

India is popular for its riverine buffaloes and these have been categorized in 5 major groups. In addition, Swamp buffaloes are also found mainly in north-eastern states of the country which are used for draught purpose. As India is one of the top most countries for milk production in the world since from last few years. As per $19^{\text {th }}$ livestock census (2014) today in India 108.70 million buffaloes produce $60 \%$ milk from the total milk production. In 2016-17 India produced 165.4 million tonnes milk. Gujarat is an important state in milk production and marketing in India on co-operative dairy system. India is the highest milk producer country in the world with an estimated quantity of 137.7 million tons in the year 2013-14 (Anonymuous, 2015). Gujarat has around 
$5.23 \%$ of cattle and $9.55 \%$ of buffalo population of the country (Anonymous, 2014b). It contributed around 10.3 million tonnes $(7.8 \%)$ of milk to the total milk pool of India and per capita milk availability was 476 g/day during 2012-13 (Anonymous, 2014a). The livestock production potential is depending on the management practice of farmers in which they are rearing and it affects very much significantly across on the economic production of the livestock of farmers. Livestock sector is one of the best economic sources in the rural areas without much more investment. The farmers are slowly moving away from the dairy sector, due to some issues like low milk rate in market, high feeding prices, management cost and the treatment cost farmer is going so far from the dairy sector. All these parameters are involved in the economic loss or gain to the farmers. Hence farmer needs to do the livestock production in more technical way to avoid economic loss. So it is very important to study the socio economy status of these farmers to know the real situation and factor affecting the dairy farming suggest improving the economic status of the farmers. Jaffrabadi is considered one of the best dairy buffalo breed in India. They are heaviest and massive type of riverine buffalo. They are good milkers and thrive well on natural grazing due to their greater feed conversion efficiency. The native breeding tract of Jaffrabadi buffalo is Saurashtra region of Gujarat, viz. Junagadh, Bhavanagar, Jamnagar, Amreli, Gir Somnath, Rajkot and Morbi district as well as some part of Surendranagar district. The local people (Kathiravan et al., 2007) also know it as "Bhavnagri”, "Gir" or "Jaffari".

\section{Materials and Methods}

The survey was conducted from of Amreli, Bhavnagar, Rajkot, Gir Somnathand Junagadh these five districts from Gujarat state during the year 2015 to 2017. Total 1045 farmers from 80Villages of different locality were included in this study. Separate software was developed in access data base forms for this survey. The data was collected by faceto-face interview and direct observation method. Farmer's demographic parameters, viz. Occupation, total herd average, watering point, land-holding condition, Milk consumption type etc. Data collected in hard forms and entered into access database system. Then data were analysed using simple statistical tools such as averages, frequencies and percentage. Data were tabulated and analysed as per standard statistical tools (Snedecor and Cochran, 1989) to draw meaningful interference

\section{Results and Discussion}

The survey was conducted in 80 villages from Amreli, Bhavnagar, Rajkot, Gir Somnath and Junagadh districts of Gujarat state. Total 3318 animals and 1045 farmers were included in the study. The analysis is divided into two aspects i.e. some attributes of farmers and few are of animal's parameters. The analysis of the conducted study is as follow-

\section{Farmers and animal's attributes} (Table no. $1 \& 2$ )

The studied parameters related to farmer's and animal's aspects are as follows:

Average herd size: In the studied survey from 1045 farmer's, maximum number of farmers were having 1 to 5 number of animal's average herd size. Farmers who were having 1 to 5 number of animals they were 527 farmers, 5to 10 animals having farmers were 305 and more than 10 animals having farmers were 213. Similar types of findings have been reported by Prajapati et al., (2016) and Sivaji et al., (2018).

Watering point: The animals were watering in the three methods i.e. Manual, Own or Own as well as co- manual. The farmers who 
used the watering as co- manual those were more in numbers. Around $56 \%$ farmers were using co-manual, 41 by own and $3 \%$ own as well as co- manual type of watering point used by farmers.

As similar it was observed that majority of the respondents depend on Bore well (68.67\%) followed by Pond $(21.33 \%)$ and Bore well as well as Pond (10\%) as a source of drinking water to their dairy animals. (G. P. Sabapara 2016).
Land holding farmers: In the survey as per the land holding of famers, they were grouped in four types' i.e. large land holding (above 2.5 acres), Marginal (1.5 to 2.5 Acres) and small (upto 1.5 Acres) and Landless. As per the data it was observed that Marginal land having farmers were $32 \%$ and after that small land holding farmers were 30 per cent, 26 $\%$ landless and $11 \%$ were having the large land holding farmers. The same groups are also as like Prajapati et al., (2016), Gautam et al., (2007) and Nagrale (2016).

Table.1 Farmers recorded attributes in survey

\begin{tabular}{|c|c|c|c|}
\hline Variables & Constraints & Total Numbers & Percentage (\%) \\
\hline \multirow[t]{5}{*}{ Farmer } & Amreli & 596 & 57 \\
\hline & Bhavnagar & 61 & 6 \\
\hline & Girsomnath & 45 & 4 \\
\hline & Junagadh & 120 & 11 \\
\hline & Rajkot & 223 & 21 \\
\hline \multirow[t]{4}{*}{ Occupation } & Agriculture & 525 & 50 \\
\hline & Dairy & 321 & 31 \\
\hline & Labour & 125 & 12 \\
\hline & Service & 74 & 7 \\
\hline \multirow[t]{3}{*}{ Animal herd Size } & 1 ( 0 to 5 animals $)$ & 527 & 50 \\
\hline & 2 (5-10 animals) & 305 & 29 \\
\hline & 3(above 10 animals) & 213 & 21 \\
\hline \multirow[t]{3}{*}{ Watering Point } & Co-Manual & 590 & 56 \\
\hline & Own & 427 & 41 \\
\hline & Own + Co-Manual & 28 & 3 \\
\hline \multirow[t]{4}{*}{ land group } & Landless & 269 & 26 \\
\hline & Large (above 2.5 acres) & 119 & 11 \\
\hline & $\begin{array}{l}\text { Marginal }(1.5 \text { to } 2.5 \\
\text { acres) }\end{array}$ & 339 & 32 \\
\hline & Small ( up to 1.5 acres) & 318 & 30 \\
\hline \multirow{3}{*}{$\begin{array}{l}\text { Type of } \quad \text { Milk } \\
\text { Consumption }\end{array}$} & Boiled & 489 & 47 \\
\hline & Raw + Boiled & 162 & 16 \\
\hline & Raw & 394 & 38 \\
\hline \multirow[t]{3}{*}{ Feeding Type } & Grazing & 454 & 43 \\
\hline & Stall feeding & 591 & 57 \\
\hline & Grand Total & 3318 & 100 \\
\hline
\end{tabular}


Table.2 Animals recorded attributes in survey

\begin{tabular}{|c|c|c|c|}
\hline Variables & Constraints & Total Numbers & $\begin{array}{l}\text { Percentage } \\
(\%)\end{array}$ \\
\hline \multirow[t]{5}{*}{ District } & Amreli & 1837 & 55 \\
\hline & Bhavnagar & 227 & 7 \\
\hline & Girsomnath & 265 & 8 \\
\hline & Junagadh & 315 & 9 \\
\hline & Rajkot & 674 & 20 \\
\hline \multirow[t]{6}{*}{ Animal Age Group } & $1(1$ to 12$)$ & 506 & 15 \\
\hline & $2(13$ to 36$)$ & 693 & 21 \\
\hline & $3(37$ to 60$)$ & 630 & 19 \\
\hline & $4(61$ to 84$)$ & 554 & 17 \\
\hline & 5 (85 to 108$)$ & 436 & 13 \\
\hline & $6(>108)$ & 499 & 15 \\
\hline \multirow{3}{*}{$\begin{array}{l}\text { Type } \\
\text { Insemination }\end{array}$} & AI & 1346 & 41 \\
\hline & $\begin{array}{l}\text { Natural } \\
\text { Service }\end{array}$ & 1972 & 59 \\
\hline & Grand Total & 3318 & 100 \\
\hline
\end{tabular}
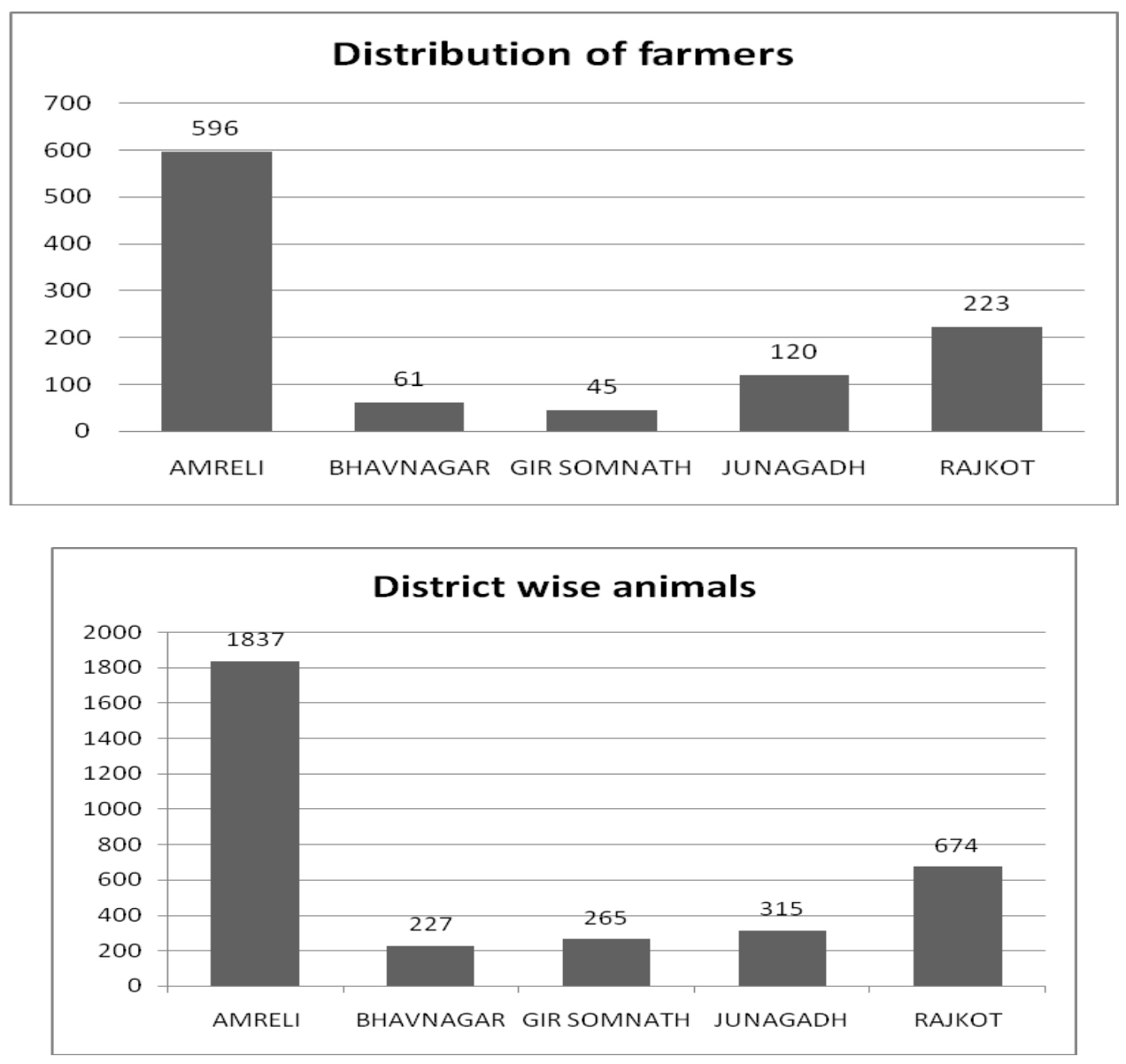
Type of milk consumption: In the study the type of milk consumption by the farmers were also recorded i.e. boiled type, Raw and Raw as well as boiled. It was observed that 47 $\%$ farmers consume boiled milk, 38 \%use raw milk and $16 \%$ farmers consume milk as raw and boiled type. As in some studies, it is found that up to a third of all raw milk samples contained pathogens, even when sourced from clinically healthy animals or from milk that appeared to be of good quality (John Lucey, 2015).

Feeding type: The feeding patterns of all 3318 animals by 1045 farmers were also studied in the survey. Stall feeding preferred by $57 \%$ farmers and $43 \%$ farmers were grazing their animals. The findings feeding is contradictory of practices majority of respondents $(84.67 \%)$ followed stall-feeding as well as grazing system, while only $15.33 \%$ of the respondents followed stall feeding system for their animals (Sabapara, 2016).

Farmer occupation: In the observed study of 1045 farmers, maximum no of farmers was having agriculture as a main economic source followed by the dairy sector. $50 \%$ farmers were having Agriculture, $31 \%$ having Dairy, $14 \%$ labour and $7 \%$ farmers were service as their main economic source in rural area. The same types of finding were recorded by Sivaji et al., (2018) as well as Gautam et al., (2007).

Animal population: Total 3318 number of animals was studied in the survey. From all animals more than half animal population from Amreli district. Animal 55\%from Amreli, 20 Rajkot, 9 Junagadh, 8 Gir Somnath and $7 \%$ from Bhavnagar in the total population.

Age group wise animals: Animals were recorded as per the age group. Six type of animals age group were recorded i.e. up to 1year age, 2-3, 4-5, 6-7, 8-9 and >9 yr. In the result it observed that 693 number of animals were from 1 to 3 year, 630 of 4 to 5 year, 554 in between 6 to 7 years, 506 up to 1 year and 499 from more than 9 years age and 436 animals in age group of 8 to 9 year.

Service type: Artificial and natural service was used to inseminate the field animals. 59 $\%$ animals were inseminated by natural service and $41 \%$ animals were inseminated by artificial insemination. The result was as like Bainwad et al., (2007) found that all animals were breed by natural services.

In conclusion, the field survey was conducted to know the first hand information of dairy husbandry practices in Saurashtra region of Gujarat with the objectives to study farmer's dairy husbandry practices and management, social and economic characteristics of dairy animal owners and knowledge level of dairy animal owners about modern dairy husbandry practices. The results showed that buffalo farming is an occupation of large respondents with no formal schooling and small land owners. The study can be concluded that clearly reveals that in Saurashtra region buffalo farming was more of agriculture linked and also one of the major source of income. Generally maximum numbers of farmers adopt natural breeding method for their buffaloes. Farmers around $59 \%$ farmers use natural breeding and $41 \%$ done the artificial insemination.

\section{Acknowledgement}

The authors are thankful to the BAIF Gujrat state team for providing coordination and essential facilities to carry out survey which funded by Department of Biotechnology.

\section{References}

Anonymous (2014a). Basic animal husbandry and fisheries statistics, AHS series-15, 
Ministry of Agriculture Department of Animal Husbandry, Dairying and Fisheries Krishi Bhawan, New Delhi. Anonymous (2014b) 19th livestock census2012 all India report, Ministry of Agriculture Department of Animal Husbandry, Dairying and Fisheries, Government of India, Krishi Bhawan, New Delhi.

Anonymous (2015) Annual Report 2014-15. Department of Animal Husbandry, Dairying and Fisheries, Ministry of Agriculture, Government of India, Krishi Bhawan, New Delhi

Bainwad, D. V., B. R. Deshmukh, B. M. Thombre and D. S. Chauha (2007) Feeding and Management Practices Adopted by Buffalo Farmers Under Watershed Area. Indian J. Anim. Res., 41 (1): 68-70.

G. P. Sabapara. (2016) Feeding Management Practices of Dairy Animals in Coastal Areas of Navsari District of India. Livestock Research International. Vol 4: 88-93.

Gautam, U. S., Chand, R. and Singh, D. K. (2007) Socio-personal correlation of Decision- making and adoption of dairy practices. Indian Research Journal Extension Education, 7(2-3): 10-11.

$19^{\text {th }}$ Livestock census, 2014. Annual report. Department of Animal Husbandry,
Dairying and Fisheries. Government of India.

Kathiravan P., Mishra B.P., Sadana D.K., Katariya, R.S. and Singh, G. 2007. Buffalo Genetic Resources of India: Jaffarabadi. Monograph, National Bureau of Animal Genetic Resources, Karnal

Nagrale, S. G. (2016) Studies on feeding and management practices adopted in livestock fodder camps during drought in Kaijtahsil of Beed district. M.Sc. (Agri.) thesis submitted to VNMKV, Parbhani.

Prajapati V.S., S. R. Ranjeet and G. M. Chaudhari (2016) Socio-Economic Status of Livestock Farmers of Navasari District of South Gujarat. International Journal of Agriculture Sciences. Volume 8: (13) pp 1182-1183.

Shivaji. D.V., K. Natchimuthu., S. Ramkumar, D. Sreekumar and R. Ganesan (2018) Socio Economic Profile of Buffalo Farmers in Guntur and Prakasam Districts of Andhra Pradesh, India. International Journal of Current Microbiology and Applied Sciences. Volume 7: (04).

Snedecor G.W. and Cochran W.G. (1989) Statistical methods (8th edn.) Oxford and IBH Publishing Co., New Delhi.

\section{How to cite this article:}

Shilpa Jayebhaye, Menka Jayebhaye, Vinod Potdar, Tejashree Shirsath, Velu Dhanikachalam, Santosh Kumar Jadhav, Suresh B. Gokhale and Marimuthu Swaminathan. 2020. Socio Economic Profile of Jaffrabadi Buffalo Farmers in Saurashtra Region. Int.J.Curr.Microbiol.App.Sci. 9(05): 1151-1156. doi: https://doi.org/10.20546/ijcmas.2020.905.126 